\title{
A Educação Física no Ensino Médio integrado: Análise de teses e dissertações defendidas em programas brasileiros de pós-graduação
}

\author{
Physical Education in integrated High School: Analysis of theses and dissertations defended in
}

\author{
Brazilian post-graduation programs
}

La Educación Física en la Escuela Secundaria integrada: Análisis de tesis y disertaciones

defendidas en programas de posgrado brasileños

Recebido: 17/03/2021 | Revisado: 23/03/2021 | Aceito: 25/03/2021 | Publicado: 02/04/2021

\author{
Everton de Souza \\ ORCID: https://orcid.org/0000-0001-6695-0891 \\ Universidade do Estado de Santa Catarina, Brasil \\ E-mail: everton-sou@ hotmail.com \\ Larissa Cerignoni Benites \\ ORCID: https://orcid.org/0000-0001-6144-5298 \\ Universidade do Estado de Santa Catarina, Brasil \\ E-mail: lari.benites@gmail.com
}

\begin{abstract}
Resumo
Esta pesquisa teve como objetivo mapear e analisar a produção acadêmica em teses e dissertações - defendidas em programas brasileiros de pós-graduação - que versam sobre a Educação Física no ensino médio integrado (EMI). A presente investigação caracteriza-se como uma pesquisa de abordagem quali-quantitativa com delineamento bibliográfico e análise bibliométrica. A busca pelos trabalhos foi realizada em duas bases de dados brasileiras por meio dos descritores "Educação Física" e "ensino médio integrado" e com a utilização do operador booleano AND. Concluiu-se que a Educação Física se manifesta de maneira singular em cada instituição em que há a oferta do EMI e que a disciplina é um componente curricular essencial para essa modalidade de curso devido à capacidade que ela possui de contribuir com a formação integral dos educandos.
\end{abstract}

Palavras-chave: Educação física; Ensino médio integrado; Ensino; Teses e dissertações.

\begin{abstract}
This research focused on mapping and analyzing the academic production in theses and dissertations - defended in Brazilian post-graduation programs - related to Physical Education in integrated high school (IHS) topics. This investigation is characterized as a research of quali-quantitative approach with bibliographic design and bibliometric analysis. The search for the academic productions was made in two Brazilian databases through the descriptors "Physical Education" and "integrated high school" utilizing the boolean operator AND. It was concluded that Physical Education manifests itself in a singular way in each institution where IHS is offered and the subject is an essential curricular component for this course modality due to its ability to contribute to integral formation of students.
\end{abstract}

Keywords: Physical education; Integrated high school; Teaching; Theses and dissertations.

\section{Resumen}

Esta investigación tuvo como objetivo mapear y analizar la producción académica en tesis y disertaciones defendidas en programas brasileños de posgrado - que son sobre la Educación Física en la escuela secundaria integrada (ESI). La presente pesquisa es caracterizada como una investigación de abordaje quali-cuantitativo con delineamiento bibliográfico y análisis bibliométrico. La búsqueda pelos trabajos se realizó en dos bases de datos brasileñas utilizando los descriptores "Educación Física" y "escuela secundaria integrada", con el uso del operador booleano AND. Se concluyó que la Educación Física se manifiesta de manera única en cada institución donde se ofertas el ESI y que la disciplina es un componente curricular imprescindible para este tipo de cursos por su capacidad de contribuir a la formación integral de los estudiantes.

Palabras clave: Educación física; Escuela secundaria integrada; Ensenãnza; Tesis y disertaciones.

\section{Considerações Iniciais}

A Educação Física, enquanto componente curricular obrigatório da educação básica, deve contribuir com o processo de formação integral dos educandos (Aguiar, 2003; Lovisolo, 2002). Todavia, como alegam Brandolin, Koslinki e Soares 
(2015, p.601), nos debates educacionais sempre estiveram presentes "[...] os problemas de identidade e de legitimidade desta disciplina [...]". Tais problemas fazem com que a Educação Física seja comumente desvalorizada no âmbito educacional, isto é, conforme aponta Vasconcelos e Campos (2014), seja julgada como de menor importância pedagógica ${ }^{1}$.

Marques e Gawryszewski (2018, p.169), ao comentarem sobre o assunto, destacam que ainda hoje a Educação Física - no senso comum - é entendida como "[...] uma disciplina escolar destinada a ser um instrumento de ocupação do tempo vago e recreação [...]". Os autores acrescentam:

Nessa visão, a intervenção pedagógica seria menos complexa, pois esse trabalhador docente não teria necessidade de organizar o conhecimento e agiria em um improviso constante, cuja função está muito mais associada em ocupar os alunos do que levar possibilidades de ensino sistematizado. Nessa visão corrente, na maioria das vezes o trabalho do professor é visto como dispensável e como um conjunto de atividades sem importância, onde qualquer um pode fazer essa tarefa independente de formação (Marques; Gawryszewski, 2018, p.169).

Modificar esse cenário de desprestígio da disciplina no âmbito escolar não é uma tarefa fácil, uma vez que Brandolin, Koslinki e Soares (2015) evidenciam que, a partir da década de 1980, os pesquisadores² de maior destaque da Educação Física brasileira debruçaram seus estudos, com base em diferentes vertentes ideológicas e teóricas, sobre a crise de identidade e de legitimidade da disciplina.

A falta de reconhecimento da importância da Educação Física no ambiente escolar, aliada aos problemas que a cercam, faz que ela perca espaço nesse meio. Observamos tal fato na Medida Provisória no 746, de 22 de setembro de 2016 (Brasil, 2016), a qual não trouxe no texto original a obrigatoriedade do ensino da Educação Física no ensino médio. Após uma mobilização nacional de alunos, profissionais da educação e diversas entidades da área, a não obrigatoriedade da Educação Física foi revertida pela Lei $n^{\circ}$ 13.415/2017. No parágrafo $2^{\circ}$ do artigo $3^{\circ}$ da referida lei, consta: “[...] A Base Nacional Comum Curricular referente ao ensino médio incluirá obrigatoriamente estudos e práticas de educação física, arte, sociologia e filosofia" (Brasil, 2017, s/p).

Embora a não obrigatoriedade da Educação Física no ensino médio tenha sido revertida, ficou o alerta para os profissionais e entidades de educação em relação às intenções do Estado no que se refere à Educação Física - além de outras disciplinas como Arte, Sociologia e Filosofia - nesse nível de ensino.

De toda maneira, a constituição da Educação Física no ensino médio propedêutico/tradicional é rodeada por fatores que afetam negativamente sua legitimidade e seu reconhecimento enquanto componente curricular essencial para o desenvolvimento dos escolares (Brandolin; Koslinki; Soares, 2015; Marques; Gawryszewski, 2018). Todavia, a inquietação que levou à construção dessa pesquisa é: como a Educação Física tem se constituído no ensino médio integrado (EMI) ${ }^{3}$ ?

Talvez a melhor resposta que se pode dar para esse questionamento é que a Educação Física se manifesta e se constitui em cada contexto de maneira específica. Afirmamos isso com base em autores como Sayão (2019), que, ao comentar sobre a Educação Física na educação profissional e tecnológica (EPT), esclarece que não há somente uma maneira de conceber a atuação dessa disciplina:

[...] mas uma diversidade de possibilidades, e ainda, que a forma como se constitui essa atuação está diretamente relacionada com as perspectivas assumidas frente às questões que atravessam a educação física, a inserção dessa

\footnotetext{
${ }^{1}$ Embora vários estudos destacarem que a Educação Física é percebida como uma disciplina de menor importância, há estudos em instituições específicas que apontam que a Educação Física é vista pelos atores escolares com a mesma importância que as demais disciplinas, como exemplo citamos o estudo de Sampaio (2010) em uma Escola Agrotécnica Federal - atualmente Instituto Federal de Educação, Ciência e Tecnologia Baiano - Campus Santa Inês e o estudo de Gariglio (2002) no CEFET-MG.

${ }^{2}$ Brandolin, Koslinki e Soares (2015) citam autores como João Paulo Subira Medina, Vilma L. Nista Piccolo, Mauro Betti, Hugo Rodolfo Lovisolo, Go Tani, Valter Bracht, Adroaldo Gaya, Celi Nelza Zülke Taffarel, Elenor Kunz, Carmen Lúcia Soares, entre outros.

${ }^{3}$ Modalidade de curso, pertencente à EPT, que propicia a formação geral de caráter propedêutico em conjunto com a formação técnica de nível médio em uma única grade curricular.
} 
disciplina na educação profissional e as questões que dizem respeito à constituição da própria educação profissional [...]" (Sayão, 2019, p.284).

Gariglio (2002, p.73) contribui com a discussão, pois, ao investigar a Educação Física no CEFET-MG, o pesquisador constatou que havia na instituição "[...] uma inércia pedagógica e institucional dotada de prioridades e necessidades que lhe são próprias, locais e imediatas". Para ele, isso "[...] faz com que se produzam tradições pedagógicas que se acabam constituindo uma referência organizadora do trabalho dos professores" (Gariglio, 2002, p.73).

A Educação Física no EMI é um campo de atuação rodeado por incertezas, principalmente pelo fato de os estudos que versam sobre o assunto terem ganhado notoriedade apenas nos últimos anos devido ao Decreto $\mathrm{n}^{\circ}$ 5.154/2004 e à Lei $\mathrm{n}^{\circ}$ 11.892/2008, que, respectivamente, regulamentou o EMI e criou os Institutos Federais de Educação, Ciência e Tecnologia. Silva, Silva e Molina Neto (2016, p.327) ratificam que "[...] a constituição dos Institutos Federais e a contribuição da Educ ação Física para a Educação Profissionalizante têm despertado, de modo incipiente, a atenção de alguns pesquisadores [...]". Os autores que têm direcionado suas pesquisas para esse campo, como Santos e Rosset (2019), afirmam que são poucas as investigações que se dedicam a compreender os pressupostos históricos, a legitimidade e as possibilidades pedagógicas da Educação Física no contexto da EPT.

No entanto, alguns estudos realizados têm mostrado que a Educação Física no EMI tem adquirido características semelhantes à Educação Física no ensino regular. Santos e Rosset (2019), por exemplo, em uma pesquisa bibliográfica e documental, chegaram à conclusão de que a Educação Física que se materializa na EPT não possui uma identidade própria que seja coerente com a proposta de formação dessa modalidade de ensino, isto é, uma formação politécnica. Os autores entendem que, nesse contexto, a Educação Física "[...] constitui uma relação de integração artificial, não se diferenciando da relação estabelecida com a educação propedêutica" (Santos; Rosset, 2019, p.14).

Outros pesquisadores que chegaram a essa mesma conclusão foram Boscatto e Darido (2017) ao investigarem a Educação Física em um Instituto Federal localizado no estado de Santa Catarina. De acordo com os autores:

[...] a atuação pedagógica da EF no Ensino Médio Integrado na instituição investigada possui características semelhantes a dados de outros estudos desenvolvidos no Ensino Regular. Isso fica evidente pelo fato de os professores entenderem ser a finalidade da EF no Ensino Médio Integrado contribuir com a promoção de saúde dos estudantes e com a compreensão crítica dos demais conteúdos de ensino. Tal entendimento evidenciou-se, também, nos planejamentos de ensino dos professores. (Boscatto; Darido, 2017, p.108).

Boscatto e Darido (2017, p.108) acrescentam que, devido à Educação Física no EMI possuir as mesmas características apresentadas na educação básica, é necessário que seja realizada a adequação das “[...] finalidades e conteúdos de ensino se quiserem superar o dualismo entre ensino propedêutico e ensino profissional como citam os documentos para essa modalidade de ensino".

Todavia, Silva e Fraga (2014, p.270), ao pesquisarem o retorno da disciplina de Educação Física em uma instituição federal no Rio Grande do Sul, constaram que “[...] em seu retorno, as características da EF (de tradição propedêutica) parecem ter sido fortemente influenciadas pela cultura profissionalizante [...]" da instituição. Para os autores, isso indica a abertura da possibilidade de se pensar em uma Educação Física articulada com as especificidades do EMI.

Silva (2014), ao estudar o contexto histórico-social e cultural acerca da Educação Física no currículo de quatro Câmpus do Instituto Federal do Rio Grande do Sul, constatou que está ocorrendo um processo de 'mutação' da Educação Física nas instituições. $\mathrm{O}$ autor ressalta que: 
Ainda me parece cedo para afirmar que características da EFi vão se modificar em meio a esse processo, pois não há como prever que "mutações" serão benéficas, nem mesmo que "mutações" serão "maléficas". Contudo, uma coisa é certa, um importante processo de "mutação" está sendo iniciado para a EFi nessas Escolas (Silva, 2014, p.134).

Logo, repensar a organização e a atuação da Educação Física no EMI se faz necessário para que essa disciplina adquira uma identidade própria nas instituições profissionalizantes e para que esteja de acordo com as peculiaridades desse contexto, possibilitando, assim, que se caminhe em direção a uma integração curricular sob a perspectiva da formação integrada.

Diante do exposto, essa pesquisa teve como objetivo mapear e analisar a produção acadêmica em teses e dissertações - defendidas em programas brasileiros de pós-graduação - que versam sobre a Educação Física no EMI. Para tal, foi realizada uma pesquisa de revisão bibliográfica com análise bibliométrica dos trabalhos disponibilizados em duas bases de dados brasileiras. Essa pesquisa justifica-se pela necessidade de legitimidade da Educação Física no EMI. Logo, compreende-se que todas as pesquisas que se propõem a discutir a temática são relevantes, uma vez que podem contribuir para a construção de uma Educação Física mais alinhada às finalidades dessa modalidade de curso.

\section{Encaminhamentos Metodológicos}

Essa investigação caracteriza-se como uma pesquisa de abordagem qualitativa com delineamento bibliográfico e que se valeu de alguns elementos quantitativos por meio da análise bibliométrica (Pereira et al, 2018). Os trabalhos científicos analisados foram teses e dissertações produzidas no país e que versam sobre a Educação Física no EMI. Para tal, foi realizada uma busca na base de dados da Biblioteca Digital Brasileira de Teses e Dissertações (BDTD) e no Catálogo de Teses e Dissertações da Capes por meio dos seguintes descritores: ‘ensino médio integrado' e ‘Educação Física'.

Para restringir a busca a teses e dissertações que possuíam ambos os descritores pesquisados, optou-se por utilizar o operador booleano AND, dessa maneira, a busca foi realizada nas duas bases com a seguinte combinação: "ensino médio integrado" AND "Educação Física”.

Para selecionar os trabalhos, foram aplicados os seguintes critérios de inclusão: a) divulgação autorizada do trabalho pelo pós-graduando; b) o trabalho possuir como objeto de estudo a Educação Física - ou temas da área da Educação Física no EMI; e c) que tenha sido defendido em programa de pós-graduação brasileiro. Os critérios de exclusão aplicados foram: a) o trabalho discorrer sobre a Educação Física - ou temas da área da Educação Física - no Programa Nacional de Integração da Educação Profissional com a Educação Básica na Modalidade de Educação de Jovens e Adultos (Proeja ${ }^{4}$; b) trabalhos duplicados; e c) trabalho não atender aos três critérios de inclusão.

Optou-se por não restringir a busca no que se refere ao ano de defesa das produções e foram lidos na íntegra os resumos de todas as teses e dissertações encontradas. Também foi realizada uma busca de outras informações no corpo dos trabalhos para verificar se atendiam aos critérios de inclusão.

\section{Resultados e Discussão}

A busca na Biblioteca Digital Brasileira de Teses e Dissertações foi realizada no dia 12 de janeiro de 2021. Nessa busca foram encontrados dezesseis resultados. Todas as produções encontradas na busca na BDTD possuíam divulgação autorizada e links que direcionam para os locais dos trabalhos.

Após uma primeira análise, uma tese e uma dissertação foram excluídas porque não abordavam a Educação Física ou temas da área da Educação Física - no EMI. Nenhum dos trabalhos encontrados na BDTD versava sobre o Proeja e todos

\footnotetext{
${ }^{4}$ No que tange ao Proeja, consideramos que a Educação Física nessa modalidade de curso deve ser objeto de pesquisas que se dediquem exclusivamente a compreender a disciplina nesse contexto.
} 
foram defendidos em programas brasileiros. Portanto, foram selecionados quatorze trabalhos da BDTD para uma análise detalhada.

No dia 13 de janeiro de 2021, foi realizada a busca no Catálogo de Teses e Dissertações da Capes, no qual foram encontrados vinte e três resultados. Nas primeiras análises, duas teses foram excluídas, uma por não apresentar a divulgação autorizada, e outra por ter como ênfase o Proeja. Uma terceira dissertação foi excluída por não versar sobre a Educação Física - ou temas da disciplina - no EMI, embora apresentasse ambos os descritores.

Ao comparar os resultados da busca realizada no Catálogo de Teses e Dissertações com os resultados da BDTD, observou-se a duplicação de onze resultados. Portanto, foram selecionados somente nove trabalhos do Catálogo de Teses e Dissertações da Capes para serem analisados. Dessa maneira, considerando as duas bases de dados, foram selecionadas vinte e três produções - cinco teses e dezoito dissertações - para serem estudados detalhadamente.

Os anos de defesa dos trabalhos foram entre 2008 e 2020. É possível observar que as teses e dissertações sobre a Educação Física no EMI foram produzidas principalmente a partir da década de 2010. Esse crescimento ocorreu logo após o início da expansão das instituições pertencentes à rede federal que oferecem cursos de EMI, as quais foram beneficiadas pela Lei n ${ }^{\circ} 11.892 / 2008$, que criou os IFs e instituiu a Rede Federal de Educação Profissional, Científica e Tecnológica.

Gráfico 1. quantidade e ano de defesa das teses e dissertações sobre a Educação Física no ensino médio integrado selecionadas na Biblioteca Digital Brasileira de Teses e Dissertações e no Catálogo de Teses e Dissertações da Capes.

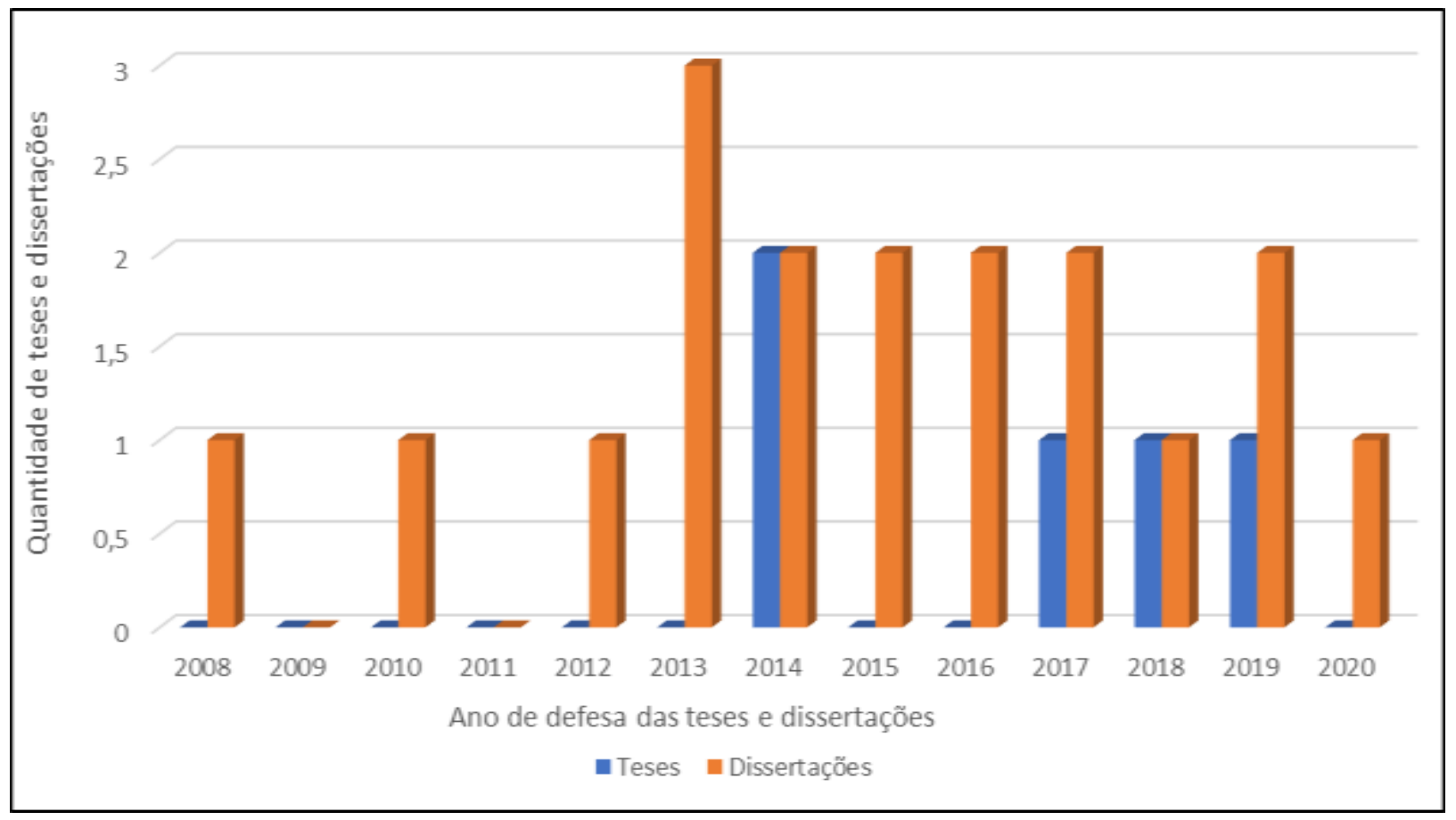

Fonte: Autores.

Certamente o aumento da oferta do EMI, que é provido principalmente pelos institutos federais, cuja prioridade devem ser cursos integrados no tocante à educação profissional técnica de nível médio (Brasil, 2008), chamou a atenção dos pós-graduandos da área. Esses começaram a buscar compreender a Educação Física nesse contexto e, assim, direcionaram suas pesquisas para a temática. Os professores que lecionam nos institutos federais e que buscam qualificação profissional em nível strictu sensu também contribuíram para esse crescimento, pois não é raro ler nas teses e dissertações que os pós-graduandos que são professores dessas instituições procuraram aprofundar o entendimento sobre a Educação Física nas instituições profissionalizantes. 
Vê-se tal fato, por exemplo, na tese de doutorado de Silva (2014), na qual o autor relata brevemente a sua experiência ao deparar-se com a realidade de um Câmpus do Instituto Federal do Rio Grande do Sul quando assumiu um concurso público como professor de Educação Física. Segundo o autor, ao chegar ao Câmpus, encontrou peculiaridades próprias do contexto e que são totalmente diferentes das realidades escolares que conhecia. $\mathrm{O}$ autor relata que se viu diante de muitas questões sem respostas e salienta:

[...] foi justamente a busca por essas respostas que me motivaram a retornar à vida acadêmica [...] e a propor o desenvolvimento desta Tese de Doutorado, no intuito de melhor compreender a história da EFi no currículo das Escolas Profissionalizantes da Rede Federal (Silva, 2014, p.12).

Além do mais, como relata Oliveira e Nunes (2017, p.202), os professores dos institutos federais “[...] são estimulados à qualificação (mestrado e doutorado), dispõem de laboratórios, estruturas para pesquisa e extensão [...]", além de jornadas de trabalhos flexíveis. Tais fatores contribuem para que esses profissionais sejam valorizados e estejam constantemente desenvolvendo pesquisas nas próprias instituições em que trabalham e em programas de pós-graduação, quando os frequentam.

Na Tabela 1, constam os autores, os tipos de produções e o título e objetivo das teses e dissertações analisadas, após serem selecionadas.

Tabela 1. tipo de produção, título e objetivo das teses e dissertações que versaram sobre a Educação Física no ensino médio integrado.

\begin{tabular}{|c|c|c|}
\hline \multicolumn{3}{|c|}{ Dissertações } \\
\hline Autor & Título & Objetivo \\
\hline $\begin{array}{l}\text { Feitosa } \\
(2008) \text {. }\end{array}$ & Educação Física: até que ponto educa? & $\begin{array}{l}\text { Verificar as principais contribuições da Educação } \\
\text { Física escolar na educação integral dos educandos. }\end{array}$ \\
\hline $\begin{array}{c}\text { Sampaio } \\
(2010)\end{array}$ & $\begin{array}{l}\text { O Componente Curricular Educação } \\
\text { Física no Ensino Médio Integrado da } \\
\text { Escola Agrotécnica Federal de Santa } \\
\text { Inês/BA. }\end{array}$ & $\begin{array}{l}\text { Investigar o componente curricular Educação Física no } \\
\text { Ensino Médio Integrado da Escola Agrotécnica } \\
\text { Federal de Santa Inês/BA. }\end{array}$ \\
\hline $\begin{array}{l}\text { Otte } \\
(2012)\end{array}$ & $\begin{array}{l}\text { Intervenção em Educação Física Escolar: } \\
\text { promovendo atividade física e saúde no } \\
\text { Ensino Médio. }\end{array}$ & $\begin{array}{l}\text { Analisar a implantação do projeto "Educação Física +: } \\
\text { Praticando Saúde na Escola" junto à disciplina de } \\
\text { Educação Física no ensino médio integrado da rede } \\
\text { pública federal. }\end{array}$ \\
\hline $\begin{array}{c}\text { Ferreira } \\
(2013)\end{array}$ & $\begin{array}{l}\text { Educação do Corpo pela Dança na } \\
\text { Escola Profissionalizante: o contexto do } \\
\text { Instituto Federal de Educação, Ciência e } \\
\text { Tecnologia da Bahia - IFBA. }\end{array}$ & $\begin{array}{l}\text { Identificar como é compreendida a dança presente no } \\
\text { Instituto Federal de Educação, Ciência e Tecnologia da } \\
\text { Bahia - IFBA. }\end{array}$ \\
\hline $\begin{array}{c}\text { Sousa } \\
(2013)\end{array}$ & $\begin{array}{l}\text { A Aplicação dos Temas Transversais nas } \\
\text { Aulas de Educação Física - Ensino } \\
\text { Médio Integrado. }\end{array}$ & $\begin{array}{l}\text { Apresentar e discutir uma experiência pedagógica na } \\
\text { educação Física escolar, a partir da operacionalização } \\
\text { de temas transversais com os conteúdos curriculares } \\
\text { no ensino médio integrado do IFRN, Campus SGA. }\end{array}$ \\
\hline $\begin{array}{l}\text { Pupatto } \\
\text { Júnior } \\
(2013)\end{array}$ & $\begin{array}{l}\text { A Educação Física no Ensino Médio } \\
\text { Integrado do Instituto Federal de } \\
\text { Educação de Mato Grosso - Câmpus } \\
\text { Juína. }\end{array}$ & $\begin{array}{l}\text { Analisar a contribuição da disciplina Educação Física } \\
\text { para a formação humana e profissional dos estudantes } \\
\text { do Curso Técnico em Meio Ambiente do IFMT - } \\
\text { Campus Juína, considerando a percepção dos } \\
\text { discentes. }\end{array}$ \\
\hline $\begin{array}{c}\text { Silva } \\
(2014)\end{array}$ & $\begin{array}{l}\text { Uma abordagem Crítica do conteúdo } \\
\text { Esporte nas Aulas de Educação Física no } \\
\text { Ensino Médio Integrado. }\end{array}$ & $\begin{array}{l}\text { Apresentar uma proposta de intervenção pedagógica } \\
\text { na disciplina de Educação Física para o Ensino Médio } \\
\text { com o conteúdo Esporte, elaborada, planejada e }\end{array}$ \\
\hline
\end{tabular}


executada com base numa abordagem crítica de ensino.

Porto Educação Física e Formação Humana: (2014) estudo crítico sobre o ensino de Educação Física e Politécnica no Instituto Politécnico da UFRJ em Cabo Frio/RJ.

Boynard A Prática Pedagógica do Docente da

(2015) Disciplina Educação Física no Instituto Federal Fluminense Campus Centro: desvendando saberes e práticas.

Ramos Participação de Alunos do Ensino Médio (2015) Integrado ao Ensino Profissionalizante em Atividade Extracurriculares de Esporte e Lazer em Campus de um Instituto Federal em Minas Gerais - MG.

\begin{tabular}{cl} 
Mendonça & \multicolumn{3}{l}{ Narrativas de Experiências Profissionais } \\
(2016) & de Docentes de Educação Física no \\
& Ensino Técnico Integrado do Instituto \\
& $\begin{array}{l}\text { Federal de Educação, Ciência e } \\
\text { Tecnologia. }\end{array}$ \\
\hline Barreto & Obesidade na Adolescência: a \\
Filho & interdisciplinaridade como estratégia de \\
$(2016)$ & promoção da saúde.
\end{tabular}

Ferreira Organização Didática da Educação

Junior Física no Ensino Médio Integrado: a

(2017) configuração da Rede Estadual de Educação Profissional do Ceará.

Soares O Currículo Prescrito da Educação Física

(2017) num Contexto de Ensino Médio Integrado.

Nascimento Dos Filtros do Instagram à Quadra da

(2018) Escola: representações sociais do corpo na perspectiva dos/as adolescentes.

Andrade O Jogo a Partir da Perspectiva Crítico-

(2019) Superado nas Aulas de Educação Física no Ensino Médio Integrado: desafios e possibilidades.

Caetano Práticas Corporais de Aventura: recurso

(2019) didático-pedagógico para integração curricular em cursos do eixo tecnológico recursos naturais na Rede Federal de Educação Profissional e Tecnológica brasileira.

Galhardo O Ensino do Conteúdo Jogos na

(2020) Educação Física: possibilidade e desafios.
Apreender e analisar criticamente os fundamentos filosóficos e científicos da proposta políticopedagógica

do IPUFRJ.

Conhecer os saberes e as práticas dos docentes da Educação Física do IFF Campos Centro.

Verificar a participação dos alunos dos cursos profissionalizantes integrados ao Ensino Médio nas atividades do programa de esporte e lazer, (PEL), desenvolvidas em um Campus de um Instituto Federal, assinalando possíveis caminhos para a otimização do programa de atividades de

esporte e lazer.

Analisar e interpretar as experiências profissionais dos docentes de Educação Física do Instituto Federal de Educação Ciência e Tecnologia do Espírito Santo/IFES.

Desenvolver um programa interdisciplinar participativo que venha a contribuir para a conscientização dos estudantes do $1^{\circ}$ ano do ensino médio quanto à redução do sobrepeso.

Identificar a configuração da Educação Física na Rede Estadual de Educação Profissional do Ceará, bem como a compreensão de educação física por parte dos professores.

Analisar os planos de ensino da disciplina Educação Física nos cursos técnicos integrados ao ensino médio do Instituto Federal do Espírito Santo (Ifes).

Compreender como os/as adolescentes pensam o corpo, na perspectiva das RS, em contextos como a Educação Física Escolar e o Instagram.

Compreender o papel da Educação Física no Ensino Médio Integrado, a partir da Perspectiva CríticoSuperadora, entendendo os desafios e possibilidades para a apropriação da Cultura Corporal, através do Jogo.

Analisar a viabilidade da inserção das Práticas Corporais de Aventura no currículo da Educação Profissional e Tecnológica, através da Educação Física escolar, nos cursos técnicos do Ensino Médio Integrado do eixo tecnológico de Recursos Naturais, numa perspectiva integradora.

Analisar uma proposta de ensino do conteúdo jogos nas aulas de Educação Física junto a uma turma de alunos do Ensino Médio integrado ao técnico de uma instituição escolar pública do interior de São Paulo. 
Research, Society and Development, v. 10, n. 4, e11610413998, 2021

(CC BY 4.0) | ISSN 2525-3409 | DOI: http://dx.doi.org/10.33448/rsd-v10i4.13998

\begin{tabular}{|c|c|c|}
\hline \multicolumn{3}{|c|}{ Teses } \\
\hline Autor & Título & Objetivo \\
\hline $\begin{array}{l}\text { Souza Filho } \\
\text { (2014) }\end{array}$ & $\begin{array}{l}\text { Novas Territorialidades Pedagógicas } \\
\text { para a Educação Física no Ensino Médio } \\
\text { Integrado: uma perspectiva pós-crítica. }\end{array}$ & $\begin{array}{l}\text { Desenvolver uma experiência pedagógica } \\
\text { fundamentada na Teoria Pós-Crítica da Educação que } \\
\text { contribua para a configuração da identidade da } \\
\text { Educação Física nos cursos técnicos de nível médio } \\
\text { integrado do IFRN - Câmpus Natal Zona Norte. }\end{array}$ \\
\hline $\begin{array}{c}\text { Viana Neto } \\
\text { (2014) }\end{array}$ & $\begin{array}{l}\text { As Abordagens Pedagógicas da } \\
\text { Educação Física que Fundamentam as } \\
\text { Formas de Uso das TIC pelos } \\
\text { Professores de Educação Física dos } \\
\text { Cursos de Técnicos Integrados ao Ensino } \\
\text { Médio do IFG. }\end{array}$ & $\begin{array}{l}\text { Identificar e analisar as Abordagens Pedagógicas da } \\
\text { Educação Física/EF que fundamentam as formas de } \\
\text { uso das Tecnologias da Informação e } \\
\text { Comunicação/TIC pelos professores de EF do EMI do } \\
\text { IFG. }\end{array}$ \\
\hline $\begin{array}{l}\text { Boscatto } \\
(2017)\end{array}$ & $\begin{array}{l}\text { Proposta Curricular para a Educação } \\
\text { Física no Instituto Federal de Santa } \\
\text { Catarina: uma construção colaborativa } \\
\text { virtual. }\end{array}$ & $\begin{array}{l}\text { Como a construção colaborativa virtual de uma } \\
\text { proposta curricular pode contribuir para a Educação } \\
\text { Física em um instituto federal localizado no estado de } \\
\text { Santa Catarina. }\end{array}$ \\
\hline $\begin{array}{c}\text { Kawashima } \\
\text { (2018) }\end{array}$ & $\begin{array}{l}\text { Sentidos e Significados da Educação } \\
\text { Física para os Alunos do IFMG - } \\
\text { Campus São Vicente: a pesquisa-ação } \\
\text { como forma de construção coletiva de } \\
\text { conhecimentos. }\end{array}$ & $\begin{array}{l}\text { Compreender como a experiência pedagógica em } \\
\text { Educação Física no ensino médio integrado ao técnico } \\
\text { em Agropecuária do IFMT - campus São Vicente } \\
\text { contribui (ou não) para apreensão e definição de } \\
\text { sentidos e significados da Educação Física pelos } \\
\text { alunos. }\end{array}$ \\
\hline $\begin{array}{c}\text { Sá } \\
(2019)\end{array}$ & $\begin{array}{l}\text { Currículo do Ensino Médio Integrado do } \\
\text { IFMG: a partitura, a polifonia e os solos } \\
\text { da Educação Física. }\end{array}$ & $\begin{array}{l}\text { Analisar o currículo do EMI do IFMG, suas conexões } \\
\text { com a Educação em Tempo Integral e com a } \\
\text { construção curricular do componente Educação Física. }\end{array}$ \\
\hline
\end{tabular}

Fonte: Autores.

A maior quantidade de dissertações que versam sobre a Educação Física no EMI pode ser compreendida pela maior oferta de programas de pós-graduação strictu sensu em nível de mestrado (Geocapes, 2019). Na Tabela 2, podem ser observadas as informações referentes às instituições e às unidades federativas em que foram defendidas as teses e dissertações, assim como a variedade de programas de pós-graduação que acabaram referendando a temática. 
Tabela 2. programas, universidades e unidades federativas em que foram desenvolvidas as teses e dissertações que versam sobre a Educação Física no ensino médio integrado.

\begin{tabular}{|c|c|c|c|}
\hline $\begin{array}{l}\text { Programa de Pós- } \\
\text { Graduacão }\end{array}$ & Autor & Universidade & Estado \\
\hline \multirow{5}{*}{ Educação Física } & $\begin{array}{c}\text { Otte } \\
(2012)\end{array}$ & Universidade Federal de Pelotas - UFPel & $\mathrm{RS}$ \\
\hline & $\begin{array}{l}\text { Mendonça } \\
(2016)\end{array}$ & $\begin{array}{c}\text { Universidade Federal do Espírito Santo - } \\
\text { UFES }\end{array}$ & $\mathrm{ES}$ \\
\hline & $\begin{array}{l}\text { Soares } \\
(2017)\end{array}$ & $\begin{array}{c}\text { Universidade Federal do Espírito Santo - } \\
\text { UFES }\end{array}$ & $\mathrm{ES}$ \\
\hline & $\begin{array}{l}\text { Ferreira Junior } \\
\quad(2017)\end{array}$ & $\begin{array}{l}\text { Universidade Federal do Rio Grande do } \\
\text { Norte - UFRN }\end{array}$ & $\mathrm{RN}$ \\
\hline & $\begin{array}{l}\text { Nascimento } \\
\quad(2018)\end{array}$ & $\begin{array}{l}\text { Universidade Federal do Vale do São } \\
\text { Francisco - UNIVASF }\end{array}$ & $\mathrm{PE}$ \\
\hline \multirow{7}{*}{ Educação } & $\begin{array}{l}\text { Sousa } \\
(2013)\end{array}$ & $\begin{array}{l}\text { Universidade Federal do Rio Grande do } \\
\text { Norte - UFRN }\end{array}$ & $\mathrm{RN}$ \\
\hline & $\begin{array}{l}\text { Silva } \\
(2014)\end{array}$ & $\begin{array}{l}\text { Universidade Federal do Rio Grande do } \\
\text { Norte - UFRN }\end{array}$ & $\mathrm{RN}$ \\
\hline & $\begin{array}{l}\text { Souza Filho } \\
\text { (2014) }\end{array}$ & $\begin{array}{l}\text { Universidade Federal do Rio Grande do } \\
\text { Norte - UFRN }\end{array}$ & $\mathrm{RN}$ \\
\hline & $\begin{array}{l}\text { Viana Neto } \\
\text { (2014) }\end{array}$ & $\begin{array}{l}\text { Pontifícia Universidade Católica de Goiás - } \\
\text { PUC/GO }\end{array}$ & GO \\
\hline & $\begin{array}{l}\text { Porto } \\
(2014)\end{array}$ & Universidade Federal Fluminense - UFF & $\mathrm{RJ}$ \\
\hline & $\begin{array}{l}\text { Kawashima } \\
\text { (2018) }\end{array}$ & $\begin{array}{l}\text { Universidade Federal de Mato Grosso - } \\
\text { UFMT }\end{array}$ & MT \\
\hline & $\begin{array}{c}\text { Sá } \\
(2019)\end{array}$ & Universidade de São Paulo - USP & SP \\
\hline \multirow{3}{*}{ Educação Agrícola } & $\begin{array}{l}\text { Feitosa } \\
(2008)\end{array}$ & $\begin{array}{l}\text { Universidade Federal Rural do Rio de } \\
\text { Janeiro - UFRRJ }\end{array}$ & $\mathrm{RJ}$ \\
\hline & $\begin{array}{l}\text { Sampaio } \\
(2010)\end{array}$ & $\begin{array}{l}\text { Universidade Federal Rural do Rio de } \\
\text { Janeiro - UFRRJ }\end{array}$ & $\mathrm{RJ}$ \\
\hline & $\begin{array}{l}\text { Pupatto } \\
\text { Júnior } \\
\text { (2013) }\end{array}$ & $\begin{array}{l}\text { Universidade Federal Rural do Rio de } \\
\text { Janeiro - UFRRJ }\end{array}$ & RJ \\
\hline \multirow[t]{2}{*}{ Ensino na Saúde } & $\begin{array}{l}\text { Boynard } \\
(2015)\end{array}$ & Universidade Federal Fluminense - UFF & RJ \\
\hline & $\begin{array}{l}\text { Barreto Filho } \\
\quad(2016)\end{array}$ & Universidade Federal Fluminense - UFF & RJ \\
\hline Dança & $\begin{array}{l}\text { Ferreira } \\
(2013)\end{array}$ & Universidade Federal da Bahia - UFBA & BA \\
\hline $\begin{array}{l}\text { Ciências do Movimento } \\
\text { Humano }\end{array}$ & $\begin{array}{l}\text { Ramos } \\
(2015)\end{array}$ & $\begin{array}{l}\text { Universidade Metodista de Piracicaba - } \\
\text { UNIMEP. }\end{array}$ & SP \\
\hline $\begin{array}{c}\text { Desenvolvimento Humano e } \\
\text { Tecnologias }\end{array}$ & $\begin{array}{l}\text { Boscatto } \\
(2017)\end{array}$ & $\begin{array}{l}\text { Universidade Estadual Paulista Júlio de } \\
\text { Mesquita Filho - UNESP }\end{array}$ & SP \\
\hline $\begin{array}{c}\text { Educação Profissional e } \\
\text { Tecnológica }\end{array}$ & $\begin{array}{l}\text { Caetano } \\
(2019)\end{array}$ & $\begin{array}{l}\text { Instituto Federal de Educação, Ciência e } \\
\text { Tecnologia Fluminense - IFFluminense }\end{array}$ & RJ \\
\hline $\begin{array}{l}\text { Educação Profissional e } \\
\text { Tecnológica }\end{array}$ & $\begin{array}{l}\text { Andrade } \\
(2019)\end{array}$ & $\begin{array}{l}\text { Instituto Federal de Educação, Ciência e } \\
\text { Tecnologia de Pernambuco - IFPE }\end{array}$ & $\mathrm{PE}$ \\
\hline $\begin{array}{l}\text { Docência para a Educação } \\
\text { Básica }\end{array}$ & $\begin{array}{l}\text { Galhardo } \\
(2020)\end{array}$ & $\begin{array}{l}\text { Universidade Estadual Paulista Júlio de } \\
\text { Mesquita Filho - UNESP. }\end{array}$ & SP \\
\hline
\end{tabular}

Fonte: Autores.

As instituições estão localizadas predominantemente na região Sudeste do país, pois sete situam-se na referida região. 
Em São Paulo estão localizadas três universidades (USP, UNESP e UNIMEP), no Rio de Janeiro encontram-se outras três instituições (UFF, UFRRJ e IFFluminense) e no Espírito Santo situa-se uma Universidade (UFES). A região Nordeste conta com quatro instituições: duas em Pernambuco (IFPE e UNIVASF), uma no Rio Grande do Norte (UFRN) e uma na Bahia (UFBA). No Centro-Oeste estão presentes duas universidades: uma em Goiás (PUC-GO) e outra em Mato Grosso (UFMT). Na região Sul do Brasil situa-se apenas uma universidade, a qual está localizada no estado do Rio Grande do Sul (UFPel).

A maior quantidade de trabalhos defendidos em instituições da região Sudeste justifica-se pela grande concentração de programas de mestrado e doutorado nessa região, sobretudo no estado de São Paulo. Os dados do Sistema de Informações Georreferenciais da Capes elucidam que, no ano de 2019, dos 4.526 programas de pós-graduação existentes no país, 1.975 estavam localizados no Sudeste, o que representa 43,63\% dos programas de pós-graduação do Brasil. Apenas no estado de São Paulo encontravam-se 929 programas, o que representa 20,52\% de todos os programas existentes no país (Geocapes, 2019).

$\mathrm{Na}$ Tabela 3, apresenta-se as principais informações referente aos aspectos metodológicos das teses e dissertações. Pode-se dizer que a abordagem qualitativa foi a observada em todos os trabalhos e apenas dois estudos registram a abordagem quanti-quali.

Tabela 3. aspectos metodológicos das teses e dissertações que versam sobre a Educação Física no ensino médio integrado.

\begin{tabular}{|c|c|c|c|}
\hline \multicolumn{4}{|c|}{ Dissertações } \\
\hline Autor & Abordagem & $\begin{array}{c}\text { Instrumento de Coleta de } \\
\text { Dados }\end{array}$ & Sujeitos \\
\hline $\begin{array}{l}\text { Feitosa } \\
(2008)\end{array}$ & Qualitativa & $\begin{array}{l}\text { Questionário e observação } \\
\text { participante. }\end{array}$ & Alunos do ensino médio integrado. \\
\hline $\begin{array}{l}\text { Sampaio } \\
(2010)\end{array}$ & Qualitativa & $\begin{array}{l}\text { Questionário, entrevista e } \\
\text { análise documental. }\end{array}$ & $\begin{array}{l}\text { Professor de Educação Física e alunos } \\
\text { do ensino médio integrado. }\end{array}$ \\
\hline $\begin{array}{l}\text { Otte } \\
(2012)\end{array}$ & $\begin{array}{l}\text { Qualitativa e } \\
\text { Quantitativa }\end{array}$ & Questionário e entrevista. & $\begin{array}{l}\text { Professores de Educação Física e alunos } \\
\text { do ensino médio integrado. }\end{array}$ \\
\hline $\begin{array}{c}\text { Ferreira } \\
(2013)\end{array}$ & Qualitativa & Entrevista. & $\begin{array}{c}\text { Professor de dança e Professor de } \\
\text { Educação Física. }\end{array}$ \\
\hline $\begin{array}{l}\text { Sousa } \\
(2013)\end{array}$ & Qualitativa & $\begin{array}{l}\text { Observação participante e } \\
\text { filmagem. }\end{array}$ & Alunos do ensino médio integrado. \\
\hline $\begin{array}{l}\text { Pupatto } \\
\text { Júnior } \\
\text { (2013) }\end{array}$ & Qualitativa & Grupo focal. & Alunos do ensino médio integrado. \\
\hline $\begin{array}{c}\text { Silva } \\
(2014)\end{array}$ & Qualitativa & Questionário e diário de campo. & Alunos do ensino médio integrado. \\
\hline $\begin{array}{l}\text { Porto } \\
(2014)\end{array}$ & Qualitativa & Análise documental. & Sem sujeitos. \\
\hline $\begin{array}{l}\text { Boynard } \\
(2015)\end{array}$ & Qualitativa & Entrevista. & $\begin{array}{l}\text { Professores de Educação Física do } \\
\text { ensino médio integrado. }\end{array}$ \\
\hline $\begin{array}{l}\text { Ramos } \\
(2015)\end{array}$ & Qualitativa & $\begin{array}{l}\text { Entrevista, questionário e } \\
\text { análise documental. }\end{array}$ & $\begin{array}{l}\text { Gestores e alunos do ensino médio } \\
\text { integrado. }\end{array}$ \\
\hline $\begin{array}{l}\text { Mendonça } \\
\text { (2016) }\end{array}$ & Qualitativa & Entrevista. & $\begin{array}{l}\text { Professores de Educação Física do } \\
\text { ensino médio integrado. }\end{array}$ \\
\hline $\begin{array}{l}\text { Barreto Filho } \\
\quad(2016)\end{array}$ & Qualitativa & Entrevista. & $\begin{array}{l}\text { Professores de Educação Física do } \\
\text { ensino médio integrado. }\end{array}$ \\
\hline $\begin{array}{l}\text { Ferreira Junior } \\
\text { (2017) }\end{array}$ & Qualitativa & Questionário. & $\begin{array}{l}\text { Professores de Educação Física do } \\
\text { ensino médio integrado. }\end{array}$ \\
\hline
\end{tabular}




\begin{tabular}{|c|c|c|c|}
\hline $\begin{array}{l}\text { Soares } \\
(2017)\end{array}$ & Qualitativa & $\begin{array}{l}\text { Entrevista e análise } \\
\text { documental. }\end{array}$ & $\begin{array}{l}\text { Professores de Educação Física do } \\
\text { ensino médio integrado. }\end{array}$ \\
\hline $\begin{array}{l}\text { Nascimento } \\
\quad(2018)\end{array}$ & Qualitativa & Entrevista e grupo focal. & Alunos do ensino médio integrado. \\
\hline $\begin{array}{l}\text { Andrade } \\
\text { (2019) }\end{array}$ & Qualitativa & Questionário e diário de campo. & Alunos do ensino médio integrado. \\
\hline $\begin{array}{l}\text { Caetano } \\
(2019)\end{array}$ & $\begin{array}{l}\text { Qualitativa e } \\
\text { quantitativa. }\end{array}$ & $\begin{array}{l}\text { Entrevista, questionário e diário } \\
\text { de campo. }\end{array}$ & $\begin{array}{l}\text { Professores e alunos do ensino médio } \\
\text { integrado. }\end{array}$ \\
\hline $\begin{array}{l}\text { Galhardo } \\
\text { (2020) }\end{array}$ & Qualitativa & $\begin{array}{l}\text { Diário de campo, roda de } \\
\text { conversas e questionário. }\end{array}$ & Alunos do ensino médio integrado. \\
\hline \multicolumn{4}{|c|}{ Teses } \\
\hline Autor & Abordagem & $\begin{array}{c}\text { Instrumento de Coleta de } \\
\text { Dados }\end{array}$ & Sujeitos \\
\hline $\begin{array}{l}\text { Souza Filho } \\
\text { (2014) }\end{array}$ & Qualitativa & Diário de campo. & Alunos do ensino médio integrado. \\
\hline $\begin{array}{l}\text { Viana Neto } \\
\text { (2014) }\end{array}$ & Qualitativa & $\begin{array}{c}\text { Análise documental, } \\
\text { Observação participante e } \\
\text { questionário. }\end{array}$ & $\begin{array}{l}\text { Professores de Educação Física do } \\
\text { ensino médio integrado. }\end{array}$ \\
\hline $\begin{array}{l}\text { Boscatto } \\
\text { (2017) }\end{array}$ & Qualitativa & Entrevista. & $\begin{array}{l}\text { Professores de Educação Física do } \\
\text { ensino médio integrado. }\end{array}$ \\
\hline $\begin{array}{l}\text { Kawashima } \\
(2018)\end{array}$ & Qualitativa & $\begin{array}{l}\text { Questionário, filmagem, diário } \\
\text { de campo e grupo focal. }\end{array}$ & Alunos do ensino médio integrado. \\
\hline $\begin{array}{c}\text { Sá } \\
(2019)\end{array}$ & Qualitativa & $\begin{array}{c}\text { Entrevista, grupo focal e análise } \\
\text { documental. }\end{array}$ & $\begin{array}{c}\text { Diretor de planejamento e } \\
\text { desenvolvimento educacional, } \\
\text { professores de Educação Física e alunos } \\
\text { do ensino médio integrado. }\end{array}$ \\
\hline
\end{tabular}

Fonte: Autores.

No que tange aos instrumentos de coleta de dados, entrevista foi o método mais utilizado pelos pós-graduandos, sendo visto em doze trabalhos, seguido de questionário, que foi utilizado em onze investigações. Tanto o diário de campo quanto a análise documental foram utilizados em seis pesquisas. Já o grupo focal foi utilizado em quatro pesquisas, observação participante em três, e filmagem em duas. A roda de conversa foi utilizada somente em uma pesquisa. Ressalta-se que alguns trabalhos contaram com mais de um instrumento na coleta de dados.

No que se refere aos sujeitos pesquisados, quatorze investigações tiveram como participantes alunos do EMI, e onze contaram com os docentes de Educação Física que lecionam nessa modalidade de curso. Também foram abarcados professores de várias disciplinas, um diretor de planejamento e desenvolvimento educacional, os gestores de uma instituição e um professor de dança. Cada um desses sujeitos de pesquisa estava presente em um estudo. Destaca-se que alguns pós-graduandos tiveram mais de um grupo como participantes de suas pesquisas.

Após essa contextualização das informações de caráter bibliométrico, apresenta-se os principais resultados dos vinte e três trabalhos analisados nessa revisão bibliográfica na Tabela 4. 
Tabela 4. principais resultados destacados pelos pós-graduandos nas teses e dissertações.

\section{Autor}

Feitosa

(2008)

\section{Principais resultados}

Os resultados da investigação de Feitosa (2008) apontam que, no EMI da instituição pesquisada mesmo ainda existindo na sociedade uma concepção de que a Educação Física é um simples instrumento de preparação física das pessoas e que se distancia da formação educacional -, a prática pedagógica dos professores de Educação Física é “[...] respaldada numa visão e abordagem de valorização da cultura, da cooperação e reflexão da realidade, numa perspectiva crítico-transformadora, portanto educa e contribui significativamente na formação integral dos educandos" (Feitosa, 2008, p.7).

Sampaio Sampaio (2010) evidenciou em sua pesquisa que o currículo da Educação Física no Câmpus pesquisado (2010) do Instituto Federal Baiano ilustra os interesses presentes no espaço da instituição. Para o autor, a Educação Física na instituição demonstra-se preocupada, sobretudo, com os interesses dos educandos, contribuindo, dessa maneira, com a formação humana e profissional dos discentes. Tal fato faz com que os educandos tenham percepções positivas a respeito da Educação Física e a considerem como um componente formativo "importante" ou "muito importante" no EMI. Sampaio (2010) acrescenta que o grande desafio para a Educação Física é a construção de um currículo para o EMI que relacione os seus componentes curriculares com o mundo do trabalho, para que, assim, seja possível superar a cultura separatista presente nessa modalidade de curso. Na pesquisa, verificou-se que a Educação Física é percebida com o mesmo status que os demais componentes curriculares, e que seus conteúdos estão alinhados às finalidades dos cursos de EMI da instituição.

Otte Ao analisar a efetividade de um projeto de intervenção que objetivou problematizar a atividade física e a (2012) saúde no contexto escolar por meio da disciplina de Educação Física em turmas do EMI, Otte (2012) destaca que a proposta de intervenção foi bem aceita pelos docentes e pelos educandos. Segundo o autor, a proposta contribuiu para a formação crítica dos educandos no que tange à relação entre a atividade física e a saúde. Além disso, os sujeitos envolvidos avaliaram a intervenção proposta como positiva. Todavia, Otte (2012) elucida que, embora o nível de conhecimento dos alunos sobre o assunto tenha melhorado, não se observou mudanças nos níveis de atividade física realizada por eles, necessitando, dessa maneira, de observações por um período de tempo mais prolongado.

Ferreira Para Ferreira (2013, p.150), a dança na escola "[...] representa uma ampliação de possibilidades da (2013) corporalidade dos alunos [...]”, pois o sujeito, ao dançar, desenvolve consciência sobre si próprio enquanto um ser corporificado e enquanto um corpo presente no mundo. Para o autor, no EMI em que foi realizada a pesquisa, a Educação Física não contempla a dança como arte, mas, sim, como parte da cultura corporal de um povo, a qual é constituída historicamente pela humanidade por meio das experiências corporais. Todavia, Ferreira (2013, p.150) afirma que a dança enquanto conteúdo de Educação Física “[...] não é outra dança e sim a mesma que a Dança enquanto arte se apresenta. Porém, na primeira ela não é conhecimento central e sim parte constitutiva do estudo da cultura corporal".

Sousa A autora destaca que, diante de observações realizadas e dos depoimentos dos discentes, verificou-se

(2013) que em certos momentos as aulas de Educação Física no Câmpus pesquisado aproximam-se do tipo chamado "rola bola", isto é, são realizadas sem planejamento e são vistas como uma atividade qualquer, distanciando-se das características de uma prática pedagógica que deveria propiciar a vivência dos conteúdos e saberes da Educação Física. Ao realizar uma intervenção pedagógica por meio dos temas transversais da Educação Física, Sousa (2013) esclarece que os discentes permitiram-se vivenciar as práticas corporais de maneira que foi possível trabalhar os conteúdos curriculares em conjunto com os temas transversais. Isso os fez entenderem as aulas como ambientes de experiências, nos quais é possível atribuir significados às práticas. A autora ressalta que uma prática pedagógica planejada possibilita a mudança de percepção dos discentes sobre a Educação Física.

Pupatto Segundo Pupatto Junior (2013), a maioria dos discentes do EMI da instituição pesquisada entendem que Júnior a Educação Física promove valores indispensáveis ao convívio social, como, por exemplo, o respeito e a (2013) tolerância. O autor destaca que os educandos compreendem que as aulas de Educação Física propiciam o desenvolvimento de aspectos que contribuem para formação profissional. Entre os aspetos destacados pelos discentes está o espírito de liderança, o cooperativismo, o planejamento e o trabalho em grupo. Pupatto Junior (2013) concluiu que a Educação Física no EMI do Câmpus Juína do Instituto Federal de Mato Grosso está contribuindo de maneira relevante com a preparação para o trabalho e para a cidadania, assim como com o aperfeiçoando da formação ética e crítica dos educandos.

Silva Por meio de uma intervenção pedagógica em uma turma de $2^{\circ}$ ano do EMI do Instituto Federal do Rio

(2014) Grande do Norte, observou-se uma evolução nos aspetos conceituais do esporte. Por causa dessa evolução, os discentes passaram a compreendê-lo como um fenômeno sociocultural e não mais apenas como uma simples prática corporal e competitiva. O autor destaca que, por meio de uma avaliação diagnóstica, evidenciou-se que a Educação Física desenvolvida na instituição estava alicerçada no 
modelo esportivista, o qual limita-se a práticas esportivas. Por meio do entendimento dos discentes de que o esporte se manifesta nos comportamentos dos indivíduos, foi possível compreender a influência das atividades esportivas na qualidade de vida dos sujeitos. Elucidou-se, dessa maneira, a necessidade de uma Educação Física que trabalhe o conteúdo esporte por meio de práticas educativas que se voltem à formação de seres críticos e reflexivos para que, consequentemente, consigam exercer sua cidadania.

Porto Para Porto (2014, p.7), no que tange aos conteúdos e aos objetivos da Educação Física, há um (2014) distanciamento entre o previsto nos documentos norteadores da disciplina na instituição pesquisada e as práticas pedagógicas desenvolvidas pelos professores. Isso acontece pois “[...] ao mesmo tempo em que, de maneira geral, esses objetivos e conteúdos assumem caráter restrito e utilitário nos documentos-base, eles acontecem de maneira mais abrangente e reflexiva na prática pedagógica, e vice-versa". Para as aulas de Educação Física no EMI, o autor defende a utilização da pedagogia histórico-crítica, da teoria histórico-cultural e da metodologia crítico-superadora da Educação Física. Isso se deve a essas possibilitarem a construção de uma educação balizada na politecnia e atenderem aos desafios impostos por uma educação com tais pressupostos.

Boynard Segundo Boynard (2015), a formação acadêmica e a motivação para a docência influenciam fortemente (2015) a ação docente, independente da autonomia tida para a escolha da metodologia da ação educativa a ser realizada. Em sua pesquisa, o autor concluiu que existe a necessidade de reestruturar os conteúdos programáticos da Educação Física na instituição pesquisada para possibilitar a aquisição de benefícios significativos para a formação dos educandos, para que, assim, ocorram constantes evoluções nas práticas pedagógicas. Evidenciou-se que a prática pedagógica desenvolvida na disciplina de Educação Física na instituição não satisfaz os alunos nem os professores. Boynard (2015) destaca que os professores da instituição precisam mudar a sua postura para promover ações críticas que vão além do foco esportivista e tecnicista da Educação Física observada no contexto pesquisado.

Ramos Ramos (2015, p.48) constatou que, nas aulas de Educação Física, os educandos do EMI da instituição (2015) pesquisada não recebem uma educação para o lazer que possibilite a eles “[...] superar as práticas conformistas e elementares, diversificar os conteúdos culturais e conseguir discernir as imposições que a mídia cada vez mais coloca na sociedade”. Para o autor, é necessário que seja oferecida aos discentes uma educação "para" e "pelo" lazer, a qual deve ser oferecida tanto no componente curricular Educação Física quanto nas atividades extracurriculares disponibilizadas aos discentes. Ramos (2015) defende que é preciso conscientizar não somente os educandos, mas toda a comunidade escolar de que o tempo destinado ao lazer é tão relevante quanto o tempo dedicado ao trabalho.

Mendonça As experiências de maior relevância edificadas no Instituto Federal do Espírito Santo narradas pelos (2016) professores estão relacionadas ao conteúdo esporte. Tais experiencias se dão principalmente em treinamentos dos educandos em determinadas modalidades esportivas para representarem os Câmpus em competições externas. Logo, Mendonça (2016) verificou que o esporte possui maior prioridade do que os outros conteúdos nas aulas de Educação Física da instituição. Todavia, os professores apresentam diferentes concepções sobre a Educação Física no EMI, o que gera certas tensões nos diálogos existentes. Essas tensões são vistas por Mendonça (2016) como algo positivo, pois contribui com a construção de propostas para o ensino do conteúdo. A instituição oferece condições estruturais favoráveis aos professores de Educação Física para realizarem suas práticas, exceto os Câmpus que foram criados recentemente como parte da expansão da rede federal. Em relação à formação inicial dos professores, eles apresentam diferentes percepções. Alguns consideram que a formação inicial supre as exigências para a prática docente, enquanto outros acreditam que é necessário expandir as experiências durante a formação inicial para enriquecer as práticas futuras como profissionais da Educação Física. Em relação à formação continuada, os docentes compreendem que ela é fundamental e que deve contribuir com as práticas cotidianas. Mendonça (2016) afirma que o EMI continua sendo um desafio para os docentes de Educação Física pesquisados. Para o autor, o maior desafio dos professores em suas ações educativas é repensar a própria prática.

Barreto Barreto Filho (2016) dá ênfase à importância do trabalho interdisciplinar nas ações de combate à Filho obesidade na adolescência e, também, à coletividade, pois, para o autor, é de suma relevância a (2016) participação dos familiares, coordenadores, diretores etc. para que as ações se tornem efetivas nos IFs. O autor destaca que os professores de Educação Física precisam - em conjunto com os demais atores que compõem a instituição - possibilitar uma formação crítica aos educandos no que diz respeito aos novos padrões observados na sociedade.

Ferreira Ao pesquisar a Educação Física no ensino médio integrado da Rede Estadual de Educação Profissional Júnior do Ceará, Ferreira Júnior (2017) constatou que a integração curricular se dá, sobretudo, no (2017) desenvolvimento de temas que aproximam as disciplinas. A integração da Educação Física é mais observada com as disciplinas da área das Ciências da Natureza - formação geral - e com disciplinas da formação profissional de cursos da área da saúde. O autor destaca que, embora sejam observadas 
práticas inovadoras a respeito do currículo integrado, é necessário que exista uma problematização mais ampla no que tange à união entre os saberes da Educação Física e as propostas de formação dos cursos técnicos. Para Ferreira Júnior (2017), isso indica a necessidade de que as ações didático-metodológicas para a Educação Física no EMI sejam formuladas por meio de um processo reflexivo dos docentes e que, posteriormente, possibilite uma prática transformadora nessa modalidade de curso. Diferentemente do cenário encontrado por Sousa (2013), em que determinados professores não planejavam as aulas de Educação Física, Ferreira Júnior (2017) constatou que todos os docentes planejam as suas práticas pedagógicas na instituição que ele pesquisou. Todavia, essas práticas são orientadas por diferentes concepções teóricas da área, com uma certa predominância das abordagens que privilegiam o contexto cultural.

Soares Embora não exista um documento-referência para o ensino da Educação Física no Instituto Federal do (2017) Espírito Santo, os docentes da disciplina propõem focos de estudos com características que se aproximam. Foram observados conhecimentos relacionados ao corpo humano (saúde, atividade física e exercício) em todos os planos de ensino analisados. O ensino dos temas relacionados ao corpo humano não se restringiu à vertente biológica, pois foram trazidas questões socioculturais na abordagem desses temas. $\mathrm{Na}$ instituição, o conteúdo esporte apresenta prioridade em relação aos demais conteúdos da disciplina. $\mathrm{O}$ esporte institucionalizado predomina na instituição devido, sobretudo, à participação dos discentes em eventos esportivos. No trato pedagógico desse conteúdo, os professores apresentam diferentes concepções para o ensino da disciplina. Vários deles, que tiveram uma formação acadêmica tecnicista, centram o ensino do esporte apenas nos aspectos técnico-táticos, ou seja, sem considerar as demais dimensões: históricas, culturais, sociológicas etc. Todavia, em alguns planos de ensino, observou-se que determinados professores buscam superar essa visão esportivista da Educação Física e procuram trabalhar o esporte de maneira contextualizada em outras dimensões. No que tange às questões relacionadas à formação profissional, percebeu-se que os docentes propõem temas que contribuem com a formação dos discentes ao propiciar debates sobre assuntos referentes ao mundo do trabalho e que estão, direta ou indiretamente, ligados à Educação Física e à saúde.

Nascimento Em sua pesquisa, Nascimento (2018) constatou que as representações sociais dos educandos do EMI de (2018) um instituto federal em relação ao corpo perante a Educação Física estão atreladas a hábitos de condicionamento físico e à obtenção de aptidões para a prática de esportes. De acordo com o autor, essas representações fazem com que os educandos criem expectativas sobre o próprio corpo, e tais expectativas fazem com que eles demonstrem resistência em participar de aulas devido à preocupação tida diante das expectativas corporais criadas. Nascimento (2018) ainda destaca que muitos discentes, sobretudo as meninas, se dizem descontentes com o uniforme de Educação Física, por existir determinada conferência dos detalhes anatômicos íntimos por meio de opiniões e olhares dos demais colegas. Isso faz com que as adolescentes criem estratégias para se sentirem mais confortáveis nas aulas práticas. Entre as estratégias destacadas estão amarrar a blusa na cintura e usar uma blusa maior. Verificou-se também que há transposição da moda e do mundo fitness para o âmbito escolar e que alguns ideais sobre o corpo ocorrem de maneira exagerada.

Andrade Após a aplicação de uma sequência didática na disciplina de Educação Física, Andrade (2019) constatou (2019) que a maioria dos educandos mudaram as percepções a respeito da disciplina, pois passaram a perceber que as aulas de Educação Física podem possibilitar a formação de cidadãos críticos quando são pensadas a partir da perspectiva da abordagem crítico-superadora dos conteúdos. Segundo o autor, os alunos entendem que a Educação Física pode contribuir com o desenvolvimento integral deles e que os conteúdos devem ser tratados de acordo com os problemas sociopolíticos da atualidade. Dessa forma, eles conseguirão compreender a realidade que os cercam e, assim, poderão intervir nas estruturas sociais visando a transformação dessas. Andrade (2019) ressalta a importância de dar voz aos educandos nas práticas pedagógicas da Educação Física, pois, segundo o autor, as sugestões dadas pelos discentes durante a sequência didática foram muito importantes para aprimorá-la e transformá-la em um produto educacional.

Caetano Caetano (2019) concluiu que as práticas corporais de aventura são conteúdos que possuem enorme (2019) importância para a formação integrada nos cursos do eixo tecnológico de Recursos Naturais ofertados por meio do EMI, pois as especificidades dessas práticas fazem com se estabeleça relações dialógicas entre as disciplinas, o que contribui com a formação integral dos educandos. O autor destaca que, para que se atinjam todas as potencialidades das práticas corporais de aventura na educação formal, especialmente nessa modalidade de curso, é preciso que se tenha um tratamento didático-pedagógico adequado dessas práticas, evitando, assim, que elas se tornem somente mais um conteúdo com perspectivas procedimentais a ser trabalhado na disciplina de Educação Física. 
Galhardo O conteúdo jogos trabalhado na disciplina de Educação Física proporcionou aos educandos uma (2020) contextualização no que diz respeito ao tempo, espaço e sociedade, além de contribuir para o desenvolvimento da criticidade dos discentes e aguçar a curiosidade deles. A reconfiguração dos jogos na qualidade de conteúdo de Educação Física apresentou-se como um desafio, uma vez que os jogos são tidos como sinônimo de esportes pelos educandos. Galhardo (2020) evidencia que o desenvolvimento desse conteúdo se mostrou com um grande potencial de mobilização e envolvimento dos educandos nas práticas educativas da Educação Física no EMI, possibilitando ampliar a participação dos educandos nas aulas e contribuir para a apropriação dos jogos em diálogo com a realidade dos educandos.

Souza Para Souza Filho (2014), os trabalhos científicos da área da Educação Física evidenciam a necessidade Filho de diversificar as práticas pedagógicas para que se tenha uma perspectiva curricular mais heterogênea (2014) que possibilite a solidificação da disciplina nas instituições escolares. Em seu estudo, o autor afirma que a Educação Física ganha muito quando se tem os próprios educandos como parceiros na construção de saberes e conhecimentos. As experiências corporais - enquanto intervenção pedagógica nas aulas de Educação Física - precisam ocorrer por meio do diálogo, da sistematização e dos processos criativos, possibilitando para a disciplina a construção de novos modelos pedagógicos que valorizem as diversidades culturais de cada comunidade escolar. O referido autor sustenta a tese de que "[...] uma experiência pedagógica fundamentada na teoria pós-crítica da educação contribui para a consolidação da identidade pedagógica da Educação Física como componente curricular dos cursos técnicos integrados [...]" (Souza Filho, 2014, p.24).

Viana Neto Perante a análise dos dados coletados por meio de diferentes instrumentos, Viana Neto (2014) considera

(2014) que os professores pesquisados tendem a adotar as abordagens críticas da Educação Física em suas práticas pedagógicas no EMI em que lecionam. Todavia, no que se refere à utilização das TIC, os professores demonstram uma preferência a uma perspectiva instrumental, pois os conteúdos trabalhados são ministrados de maneira transmissiva. Portanto, foi possível observar contradições entre a maneira como os professores utilizam as TIC e as abordagens da Educação Física às quais aderem. O autor verificou que os professores utilizam as TIC em suas aulas em média uma vez a cada quinze dias e as utilizam objetivando promover fatores e condições que contribuam para a aprendizagem dos educandos. Viana Netto (2014) constatou que são raros os Câmpus que possuem condições adequadas para a utilização das TIC. Além disso, o autor destaca que nem todos os professores pesquisados demostram familiaridade com a utilização das TIC. Para o autor, mesmo com os Câmpus possuindo condições limitantes para o ensino da Educação Física, os professores pesquisados demonstraram criatividade para contornarem as condições adversas. O argumento que Viana Netto (2014) utiliza para justificar tal fato é a formação dos pesquisados, pois todos são mestres ou doutores.

Boscatto Segundo Boscatto (2017), devido à objetividade, rapidez e flexibilidade apresentada, as plataformas (2017) digitais são ferramentas que podem contribuir para o desenvolvimento de pesquisas e interações entre os professores que estão dispostos a encarar os problemas pedagógicos da Educação Física e também a refletir sobre a própria ação educativa. Para o autor, os elementos curriculares da Educação Física construídos de maneira colaborativa surgem como possibilidades pedagógicas direcionadas às demandas do EMI. Em sua pesquisa, Boscatto (2017) afirma que cinco professores corroboraram com a tese de que uma possível sistematização curricular da Educação Física para o EMI poderia contribuir com o avanço da aprendizagem dos educandos. Somente um professor se mostrou contrário à ideia de um documento balizador. Para esse professor, o currículo deve ser construído de acordo com as especificidades culturais locais, privilegiando uma construção coletiva com os sujeitos que fazem parte da comunidade em que a instituição está inserida. Todavia, Boscatto (2017) entende que um documento norteador para o currículo da Educação Física no EMI não exclui, necessariamente, as particularidades locais, pois trata-se de um documento que visa auxiliar os professores na organização do trabalho docente. Para os professores colaboradores, a Educação Física no EMI deve contribuir com a formação para a vida, para o exercício da cidadania e para a compreensão do contexto cultural ao qual os educandos pertencem. A formação para o trabalho está, nesse caso, inserida na dimensão cultural.

Kawashima Entre os resultados de sua pesquisa, Kawashima (2018) destaca a importância da ação pedagógica do (2018) docente para a legitimação da Educação Física, uma vez que é a partir da atuação do docente que ocorre a concretização das experiências e a construção de percepções positivas ou negativas dos educandos em relação aos conteúdos da Educação Física. Para a autora, os educandos conseguem aprender apenas os conteúdos que fazem sentido para eles. Em outras palavras, eles conseguem aprender apenas os conteúdos que relacionam consigo mesmos, com seus semelhantes e com o mundo. Devido a isso, Kawashima (2018) afirma que de nada adianta tentar legitimar a disciplina de Educação Física por meio de discursos, pois o educando que não vivenciar experiências contextualizadas não atribuirá significados aos conteúdos, e nenhum discurso reverterá as percepções dele sobre o componente. A autora acrescenta que, quando há uma prática pedagógica planejada, sistematizada e diversificada, os educandos 
apropriam-se criticamente dos conhecimentos da Educação Física.

Sá O currículo prescrito do Instituto Federal de Minas Gerais é cercado pelo discurso neoliberal, o qual

(2019) coloca as necessidades mercantis à frente das reais finalidades da educação. O discurso neoliberal está introduzido nos próprios Projetos Pedagógicos de Curso (PPC), os quais apontam a inexistência de integração curricular nos cursos do EMI da instituição. A Educação Física nos Câmpus ressignifica o que está prescrito nos PPC ao enfatizar mais a cultura, os pressupostos de formação integral, entre outros. Entretanto, em determinadas ocasiões, submete-se a discursos hegemônicos. Os estudantes pesquisados destacam que a Educação Física estimula a autonomia, a valorização das diferenças na construção de suas identidades e a construção de conhecimentos sintonizados com questões da vida cotidiana. Os estudantes reconhecem a relevância da Educação Física para a formação integral do sujeito e percebem que a disciplina possibilita um equilíbrio entre os saberes práticos e os teóricos, o qual não percebem nos currículos das demais disciplinas. As improvisações dos atores escolares dão novos significados às normativas curriculares propostas pela instituição, resultando em um currículo da Educação Física que busca se sobrepor aos problemas resultantes da falta de integração do EMI.

Fonte: Autores.

No decorrer dessa revisão bibliográfica de caráter bibliométrico, foi realizada uma breve contextualização sobre a Educação Física no EMI. Pretendeu-se compreender como a disciplina tem se constituído nessa modalidade de curso por meio do conhecimento do que tem sido investigado nas teses e dissertações desenvolvidas em programas brasileiros de pósgraduação.

\section{Considerações Finais}

Nessa pesquisa, foi possível observar que a Educação Física é um componente curricular imprescindível para o EMI devido à capacidade que ela possui de contribuir com a formação integral dos educandos. Compreendemos que os professores dessa modalidade de curso devem planejar e desenvolver as práticas pedagógicas da Educação Física de maneira que atendam aos pressupostos da formação integrada que se visa nesse tipo de curso, considerando sempre as especificidades da instituição e da comunidade escolar.

Diante da análise das teses e dissertações, uma das menções que se pode realizar é que a Educação Física no EMI se manifesta de maneira singular dentro de cada instituição, pois foi possível observar diferentes realidades ao analisarmos os trabalhos selecionados. Além disso, notamos que as pesquisas realizadas por meio de intervenções pedagógicas nas aulas da disciplina demonstraram ser importantes instrumentos para evidenciar que é possível pensar em uma Educação Física mais significativa e contextualizada às necessidades dos discentes do EMI.

Perante a realização dessa pesquisa de revisão bibliográfica, evidenciou-se a necessidade de aprofundamento das discussões sobre a Educação Física no EMI e na EPT. Dessa maneira, se faz necessário a realização de novas investigações que analisem a produção científica publicada em outras bases de dados, assim como a realização de pesquisas que se dediquem a compreender as práticas pedagógicas desenvolvidas na disciplina em instituições que oferecem essa modalidade de curso.

\section{Referências}

Aguiar, R. S. (2003). A Educação Física nas séries iniciais do ensino fundamental: importância dessa prática para o desenvolvimento integral na fase escolar. Anais do Congresso Mercosul de Cultura Corporal e Qualidade de Vida. Ijuí, RS, Brasil, 3.

Brandolin, F., Koslinski, M. C. \& Soares, A. J. G. (2015). A Percepção dos Alunos Sobre A Educação Física no Ensino Médio. Revista da Educação Física/UEM, Maringá, 26 (4), 601-610. https://doi.org/10.4025/reveducfis.v26i4.2983.

Brasil. (2008). Lei $n^{\circ} 11.89$, de 29 de dezembro de 2008. Institui a Rede Federal de Educação Profissional, Científica e Tecnológica, cria os Institutos Federais de Educação, Ciência e Tecnologia, e dá outras providências. http://www.planalto.gov.br/ccivil_03/_Ato2007-2010/2008/Lei/L11892.htm.

Brasil. (2017). Lei $n^{o} 13.415$, de 16 de fevereiro de 2017. https://www2.camara.leg.br/legin/fed/lei/2017/lei-13415-16-fevereiro-2017-784336publicacaooriginal-152003-pl.html. 
Research, Society and Development, v. 10, n. 4, e11610413998, 2021

(CC BY 4.0) | ISSN 2525-3409 | DOI: http://dx.doi.org/10.33448/rsd-v10i4.13998

Brasil. (2016). Medida Provisória $n^{\circ}$ 746, de 22 de setembro de 2016. https://www2.camara.leg.br/legin/fed/medpro/2016/medidaprovisoria-746-22-setembro2016-783654-publicacaooriginal-151123-pe.html.

Boscatto, J. D. \& Darido, S. C.; (2017). A Educação Física no ensino médio integrado à Educação Profissional e Tecnológica: percepções curriculares. Revista Pensar a Prática, Goiânia, 20 (1), 99-11. https://doi.org/10.5216/rpp.v20i1.39029.

Gariglio, J. A. (2002). A Educação Física no currículo de uma escola profissionalizante: um caso sui generis. Revista Brasileira de Ciências do Esporte, Campinas, 23 (2), 69-88. http://revista.cbce.org.br/index.php/RBCE/article/view/271.

Geocapes. (2019). Sistema de Informações Georreferenciais da Capes. Brasília. https://geocapes.capes.gov.br/geocapes/.

Lovisolo, H. (2002). Da educação física escolar: intelecto, emoção e corpo. Motriz, 8 (3), 99-103. http://www.rc.unesp.br/ib/efisica/motriz/08n3/Lovisolo.pdf.

Marques, G. S. \& Gawryszewski, B. (2018). A Educação Física e suas Possibilidade no Ensino Médio Integrado. Germinal: Marxismo e Educação em Debate, Salvador, 10 (2), 166-174. http://dx.doi.org/10.9771/gmed.v10i2.25121.

Oliveira, J. L. C. \& Nunes, C. P. (2017). A carreira docente nos Institutos Federais em comparação com outras escolas públicas. Revista Educação e Emancipação, São Luís, 10 (2), 185-204. http://dx.doi.org/10.18764/2358-4319.v10n2p185-204.

Pereira A.S. et al. (2018). Metodologia da pesquisa científica. UFSM. https://repositorio.ufsm.br/bitstream/handle/1/15824/Lic_Computacao_MetodologiaPesquisa-Cientifica.pdf?sequence $=1$

Sampaio, J. S. (2010). O Componente Curricular Educação Física no Ensino Médio Integrado da Escola Agrotécnica Federal de Santa Inês/BA. Dissertação de mestrado, Universidade Federal Rural do Rio de Janeiro.

Santos, B. S. \& Rosset, M. (2019). Educação Física e Educação Profissional: contribuições na perspectiva politécnica. Revista Mundi Engenharia, Tecnologia e Gestão, Paranaguá, 4 (1), 1-17. http://dx.doi.org/10.21575/25254782rmetg2019vol4n1741.

Sayão, M. N. (2019). A Educação Física na Educação Profissional: sentidos em disputa no Instituto Federal de Educação, Ciência e Tecnologia do Rio de Janeiro - IFRJ. Arquivos em Movimento, 15 (1), 283-297. https://revistas.ufrj.br/index.php/am/article/view/21543.

Silva, E. M. (2014). Educação Física no currículo de Escolas Profissionalizantes da Rede Federal: uma espécie em processo de mutação. Tese de doutorado, Federal do Rio Grande do Sul, Brasil.

Silva, E. M. \& Fraga, A. B. (2014). A história da Educação Física na educação profissional: entrada, saída e retorno à Escola Federal de Porto Alegre. Revista Brasileira de Educação Física e Esporte, 28 (2), 263-272. https://doi.org/10.1590/1807-55092014000200263

Silva, M. A., Silva, L. O. \& Molina Neto, V. (2015). Possibilidade da Educação Física no Ensino Médio Técnico. Movimento, 22 (1), $325-336$. https://doi.org/10.22456/1982-8918.54333.

Vasconcelos, F. F. \& Campos, P. H. F. (2014). Ancoragem da representação social da Educação Física escolar nas abordagens teóricas da Educação Física. Motrivivência, 26 (43), 164-182. https://doi.org/10.5007/2175-8042.2014v26n43p164. 